\title{
App for forebygging og håndtering av kriser
}

Av Geir Inge Hausvik

På Verdensdagen for selvmordsforebygging den 10. september 2014, lanserte Sørlandet sykehus HF mobilappen MinPlan Norge. MinPlan Norge er en elektronisk plan for forebygging og håndtering av kriser, hvor målsettingen er å forhindre selvmord, overdose og selvskading. 
LANSERINGEN SKJEDDE under et lokalt arrangement ved Universitetet i Agder, i regi av LEVE Aust- og Vest-Agder. Appen er et resultat av samarbeid mellom Sørlandet sykehus, pasientsikkerhetsprogrammet «I trygge hender 24-7», dansk helsepersonell og systemutviklere.

\section{Bakgrunn}

I 2013 arbeidet alle landets helseforetak med implementering av tiltak innen de tolv innsatsområdene i den nasjonale pasientsikkerhetskampanjen. I 2014 ble dette endret fra å være kampanje til å bli pasientsikkerhetsprogrammet «I trygge hender 24-7». For psykisk helsevern og tverrfaglig spesialisert rusbehandling (TSB) var to innsatsområder spesielt viktige - forebygging av overdosedødsfall og forebygging av selvmord.

Innen innsatsområdet selvmordsforebygging, ble det lansert fem tiltak. Ett av disse fokuserte på utskrivelse og bruk av kriseplan, både for pårørende og pasienter, fordi det er kjent forhøyet selvmordsrisiko de første månedene etter utskrivelse fra døgnbehandling. Kriseplan i tradisjonell form var allerede i bruk ved utskrivning fra Sørlandet sykehus. Planen ble skrevet ned på papir av pasient og behandler sammen, og pasienten fikk den med seg. Et av hovedproblemene med papirformatet var at kriseplanen sjelden var tilgiengelig for pasienten da det var behov for den i opptakten til en krise. Ut fra denne problemstillingen kom ideen om en elektronisk kriseplan tilgiengelig på mobiltelefon.

Gjennom flere søk på ulike mobilplattformer ble appen «Minplan» vurdert som interessant. Appen var nylig lansert i den danske AppStore (september 2013) og hadde klare paralleller til behovet som var kartlagt i Norge. Det ble opprettet kontakt med den danske idéhaveren, og arbeidet for å videreutvikle og tilpasse appen norske forhold startet. I samarbeid med «I trygge hender 24-7» er MinPlan Norge nå tilgiengelig både på iPhone- og Android-systemer kostnadsfritt og uten reklamefinansiering.

\section{Funksjoner}

MinPlan Norge er bygget opp slik at man enkelt skal kunne legge inn de viktigste elementene i kriseplanen (også kjent som mestringsplan og sikkerhetsplan). Følgende hovedfunksjoner finnes i appen:
Mine faresignaler - Bruker kan lese mer om faresignaler og legge inn egne signaler for krise.

Strategier og losninger - Her legges egne mestringsstrategier og løsninger inn. Det er også mulig å legge til selvvalgte bilder, musikk og videoer.

Nettverk - Her noteres familie, venner, fastlege eller annet helsepersonell som er bidragsytere i pasientens mestringsstrategi.

Øvrige funksioner - En egen funksion viser telefonnummer og vei til nærmeste legevakt (figur 1). Det er

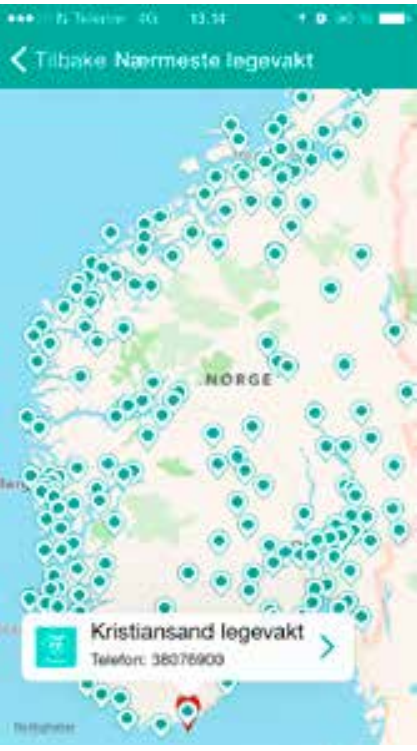

Figur 1 Nærmeste legevakt også lagt inn informasjon om hielpetelefonen til Mental Helse og Alarmtelefonen for barn og unge.

\section{Hensikt og målgrupper}

Hovedhensikten med utviklingen av MinPlan Norge er å giøre kriseplanen, som utarbeides forut for utskrivning fra behandlingsopphold i psykisk helsetjeneste, mer tilgiengelig for brukerne. Kriseplan er ett av tiltakene som kan forebygge selvmord. Ved å utarbeide kriseplanen i samarbeid med helsepersonell, blir brukeren seg bevisst de faresignalene som for henne/ham kan lede til en krise, i tillegg til egne strategier og løsninger som kan hjelpe i slike situasjoner. Appen gir okt tilgiengelighet for planen og vil kunne være med på å avverge en krisesituasjon der og da, eller den vil kunne bidra med personlige mestringsstrategier og derigiennom forhindre at krisesituasjonen får et dødelig utfall. Ambivalens, som ofte kjennetegner et selvmordstruet menneske, giør at små tiltak kan utgiøre en stor forskjell i valget mellom liv og død. 


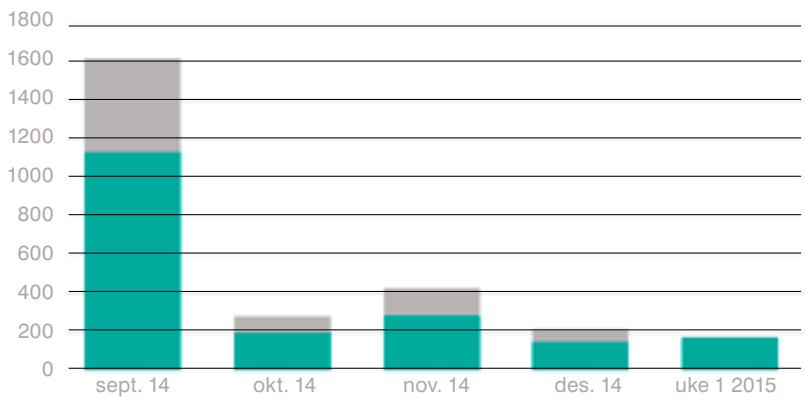

Figur 2 Antall nedlastninger pr. måned

Kriseplan kan brukes ved alle typer overgangsfaser i behandlingen som er kient for å utgiøre en høyrisikosituasion for pasienter med selvmordstanker og -planer; ved bytte av avdeling, bytte av behandler, ved permisjoner og ved utskrivning. Den er tiltenkt brukt av pasienter med selvmordsproblematikk innen hele det psykiatriske feltet; psykiatrisk poliklinikk og sengepost, tverrfaglig spesialisert rusbehandling og pasienter i barne- og ungdomspsykiatrien. Appen vil også være nyttig for pasienter med villet egenskade, både med og uten selvmordsintension.

Før lanseringen ble appen testet ut ved psykiatriske akuttposter, barne- og ungdomspsykiatrien og på avgiftningspost i rusomsorgen ved Sorlandet sykehus. Tilbakemeldingene fra utprøvingen var lovende.

I helsevesenet refereres ofte denne metodikken som «Kriseplan», «Mestringsplan» eller «Sikkerhetsplan». Det er et bevisst valg å kalle denne for «MinPlan», for å poengtere at dette skal være brukerens egen plan; det er brukeren som skal eie innholdet og selv bruke planen.

\section{Status}

Fra lanseringen i september 2014 og frem til årsskiftet 2014/2015, har MinPlan Norge blitt lastet ned ca. 2700 ganger fra Google Play og AppStore. I denne perioden har det vært mulig å svare på en kort undersøkelse i appen om opplevd nytteverdi og mulighet for å gi innspill til videre utvikling. I samme periode har 36 personer gitt tilbakemelding, hvorav 23 er personlige brukere av appen, mens 13 er helsearbeidere. Halvparten av de personlige brukerne opplever appen som «svært nyttig», mens kun én person mente at den ikke var nyttig. Av helsearbeidere opplevde 10 av 13 appen som «nyttig», «meget nyttig» eller «svært nyttig». Også her var det kun én person som mente at appen ikke var nyttig.

Noen utsagn fra brukeres tilbakemelding på appen giengis her:

«Jeg har alltid kriseplanen for hånden og jeg har tenkt mer detaljert igiennom den. 1000 takk.» (Anonym personlig bruker)

«Veldig flott produkt, med de viktigste mulighetene for hielp til selvhielp og eventuelt videre kontakt. Lett å bruke og anbefales til alle, uansett sykdom eller ei! Alle har jo dårlige dager, og denne kan være til hielp for det også.» (Anonym personlig bruker)

«Ventet lenge på kriseplan som App. Takk for den.» (Anonym helsearbeider)

Figur 2 viser antall nedlastninger på Google Play og AppStore fordelt pr. måned. Den klart største andelen av nedlastningene skjedde den forste uken etter lanseringen i september 2014. Fire måneder etter lanseringen er det fortsatt nye brukere som laster ned appen. Den første uken i januar 2015 ble den lastet ned 177 ganger.

\section{Planer fremover}

Tilbakemeldinger om feil og forslag til mindre funksionsforbedringer blir umiddelbart videresendt til utviklerne, og nye versioner blir suksessivt tilgiengeliggiort. Større endringer og forbedringsforslag blir giennomgått og drøftet med idéhaveren av appen for eventuell utvikling igangsettes.

I den danske utgaven av appen prøves det nå ut ny funksjonalitet som kan være aktuelt for MinPlan Norge:

«Sjekk inn»-funksion - Med denne funksjonen får man regelmessige påminninger om å bekrefte at man mestrer situasjonen.

Del posisjon - en funksion hvor man kan dele posisjonen man befinner seg i med kontakter som er registrert i appen. Funksionen kan brukes i kombinasjon med «Sjekk inn»-funksjonen, hvis brukeren opplever å ikke mestre situasionen.

Skyløsning - en funksionalitet som giør at brukeren kan gi kontaktpersoner, som er en del av mestringsstrategien, tilgang til planen på sine mobile enheter. Dette kan eksempelvis hielpe pårørende til å oppdage faresignaler i forkant av en krise.

Utvikling av ny funksjonalitet må giøres i samsvar med norsk lovgivning vedrørende personvern og sikker håndtering av helseopplysninger.

\section{Konklusjon}

De forelopige tilbakemeldinger viser at appen har stor klinisk nytte og relevans og virker i henhold til forventninger og forhåpninger i forhold til selvmordsforebygging. Dette er også i tråd med forskning som indikerer at helseapper gir helsegevinst (Palmer-Claus et al., 2012). Gjennom MinPlan Norge tar det norske helsevesen et skritt i retning av å forene den enkelte persons behov for oppfølging av psykisk helse med dens digitale hverdag. Generelt vil dette kunne gi en økt tilgiengelighet i oppfølgingen av den enkeltes psykiske vansker og effektivisere behandlingstilbudet.

I henhold til Nasjonalt senter for samhandling og telemedisin, ser man at sammenhengen mellom den enkelte innbyggers digitale hverdag og pasientrolle stadig utvikler seg (forskning.no, 2014). Det anses som viktig at helsevesenet også er aktiv bidragsyter her, slik som ved MinPlan Norge.

\section{REFERANSER}

forskning.no. (2014). Rask okning i bruk av helseapper. Lest 3.12.2014, http:// forskning.no/helsetieneste-helseadministrasion-mobiltelefon-informasionsteknologi/2014/o1/rask-okning-i-bruk-av

Palmer-Claus, I. E., Ainsworth, I., Machin, M., Barrowclough, C., Dunn, G., Barkus, E., ... Lewis, S. W. (2012). The feasibility and validity of ambulatory self-report of psychotic symptoms using a smartphone software application. BMC Psychiatry, $12,172$.

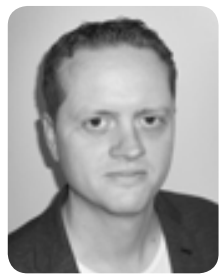

GEIR INGE HAUSVIK har 15 års erfaring som spesialrådgiver i Klinikk for psykisk helse på Sørlandet sykehus. Hans oppgaver har bla. omfattet forvaltning av pasientjournalsystemer, dataanalyse og kvalitetsforbedringsarbeid i klinikken. 